\title{
Не-места как священные места: конфрликт, противоречие или адаптация
}

\author{
Реэт Хийемяэ \\ Отделение фольклористики, Эстонский литературный музей, \\ Эстония \\ reet@folklore.ee
}

Аннотация: Французский антрополог Марк Оже ввёл термин «неместа», который он определил как городские места, где существует распространение, потребление и коммуникация вне исторических, символических и идентичностных связей. Главным объектом моего исследования является вопрос о том, в каких случаях и до какой степени такие не-места могут временно стать священными местами или духовными пространствами и, следовательно, приобрести духовное, символическое или идентичностное содержание. Я стараюсь выявить, в какой степени (временное) перемещение священного пространства в города является характерной чертой продолжающейся урбанизации и миграции, и какие изменения в духовности и пространственном восприятии связаны с данным перемещением. Я считаю, что не-места не всегда являются индикаторами отдаления от духовности, собственных корней и традиций (как утверждают некоторые авторы); скорее наоборот, их временное функционирование в качестве священных мест скорее можно считать признаком адаптации, и при определённых условиях (миграция, беженство) они могут стать спасательными кругами для духовной жизни групп и отдельных людей.

Ключевые слова: не-места, священные места, динамика традиции, нарративы, адаптация 


\section{Введение и теоретическая основа}

В современном западном обществе люди проводят всё больше времени в местах, которые Марк Оже в своей книге «Не-места. Введение в антропологию гипермодерна» (первое издание вышло в 1995 году) называет «не-местами» (например, супермаркеты, дорожные пробки, аэропорты, железнодорожные вокзалы). Не-место, по Оже, это лиминальное пространство, которое, в отличие от исторических мест, не может быть определено через связь с отношениями, историей или идентичностью (Augé 2008: 63). По мнению Оже, возникновение не-мест связано с увеличением личной свободы выбора в обществе, что приводит к бездушной гомогенности, выражающейся в не-местах, которые можно охарактеризовать исключительно функцией переходности, распространения и посредничества и отсутствием традиции, мифа и истории (см. Augé 2008: іх). Соответственно, не-места противопоставляются «антропологическим» или «историческим» местам, которые считаются «настоящими» местами, потому что они наполнены смыслом, отношениями и тесно связаны с идентичностью. Ещё за несколько лет до выхода книги Оже, в 1991 г. фрилософр Анри Лефревр предложил концепцию «абстрактных мест», у которой есть определённые сходства с не-местами Оже (см. Lefebvre 2000: 229 ff). «Абстрактными местами» Ледевр называл монофункциональные пространства, где проводятся и разрешаются только отдельные, заранее определённые мероприятия (например, с целью распространения или администрирования). Для Лефевра с триумфом абстрактного пространства над многофункциональными, общественныыми местами, такие как рынки, культовые места, исторические памятники, «распавшаяся структура ткани, то есть улицы, подземелья, окраины, порождает уже не согласие, а насилие - уже потому, что локусы, фрормы и фрункции больше не объединены, не присвоены единым центром: монументом. Пространство в целом оказывается начинено взрывным насилием» (Лефевр 2015: 220).

Идеи обоих авторов, и Лефевра, и Оже, пронизаны достаточно пессимистичным лейтмотивом: Лефевр указывает на начинённость абстрактных мест насилием, Оже (2008: хxіi) подчёркивает пассивность и беспокойство, которые люди испытывают в не-местах. Такой подход выглядит слишком однобо- 
ким. Например, было бы необходимо дополнительно осветить ментальные защитные механизмы, которые активируются в связи с не-местами, такие как субъективное воображение или нарративизащия, превращающая некоторые не-места в места, наполненные смыслом. Особенно в тех случаях, когда человек ощущает отчуждение, чувствует, что его физическая или психологическая целостность в опасности, потому что общественное пространство вмешивается в его личное пространство - что часто происходит в не-местах, согласно Оже и Лефевру, - эмоциональные реакции человека, часто сопровождаемые соответствующими соматическими реакциями (например, потоотделением) могут вызвать взволнованность, которая, в свою очередь, ведёт к процессам, связанным с психическими защитными механизмами, основывающимися на вере (например, чтение молитв, посещение молельных комнат в аэропортах, ведение внутреннего диалога с ангелом-хранителем), что помогает придать знакомое значение незнакомому месту (см. Hiiemäe 2016: 39). Такие механизмы могут также выражаться в поиске человеческих связей, желании выходить на контакт с незнакомцами, и, если эти контакты успешны, они могут превратить не-место в наполненное смыслом место с субъективной точки зрения; некоторые дружеские или даже любовные отношения, которые начинаются в таких не-местах, как тюрьмы, железнодорожные станции, временные лагеря беженцев или больницы, могут длиться десятилетиями, а иногда и всю жизнь. Таким образом, не-места могут быть отправной точкой для новых идентичностей и новых начинаний, так же как и в сказке герой обычно должен выйти в не-место, попасть в переходное пространство (на дорогу, в незнакомый город), что становится основой для событий, меняющих его или её жизнь.

Анализируя такие процессы, становится понятно, что неместа и антропологические места не являются прямыми противоположностями и что существуют гибридные формы этих мест. Одной из задач этой статьи является описание некоторых из этих форм. Главным объектом моего исследования является вопрос о том, в каких случаях и до какой степени такие не-места могут временно стать священными местами или духовными пространствами и, следовательно, приобрести духовное, символическое или идентичностное содержание. Я считаю, что их временное функционирование в качестве священных мест ско- 
рее можно считать признаком адаптации, и при определённых условиях (миграция, беженство) это является единственным способом удовлетворения духовных потребностей определённых групп и отдельных людей.

Некоторые другие авторы также выразили определённую критику теории Оже, особенно его дихотомического разделения на места и не-места в свете изменяющегося отношения между людьми и местами в эпоху постмодерна, и предложили дополнить концепцию «не-места». Например, Кристиан Трибел указывает на то, что разделение на места и не-места не может быть абсолютным, потому что это достаточно субъективные категории. Я поддерживаю идею Трибела о том, что антропологическое место одного человека может быть не-местом другого человека, и наоборот; например, аэропорт может иметь разное значение для путешественника, пилота и сотрудника наземной службы аэропорта (см. Triebel 2015: 93 f; Relph 1996). Кроме того, при наличии новых личных впечатлений не-место может стать антропологическим местом с сильными эмоциональными характеристиками и значением в жизненной истории человека (например, железнодорожный вокзал, где он впервые встретил свою будущую жену, или где появился дух умершего отца, чтобы предостеречь человека). Такие впечатления о местах, вместе с сопровождающим их нарративом, могут быть интегрированы в семейную традицию (например, в форме ежегодных посещений места). Похожие рассуждения в контексте аэропортов звучат у Максимилиано Корстанье и Роданти Тзанелли: «Возможно, социальная фонкция аэропортов не основывается на скоплении пустых значений, как предположил бы Оже, а окружена эфемерными значениями, которые (не)мобильные люди могут приписывать своим пространствам, исходя из текущей стадии своего жизнетворчества» (Korstanje \& Tzanelli 2017: 8).

Эмер О’Беерн (O’Beirne 2006: 49) также подчёркивает, что исследователи должны рассматривать не-места, используя более разносторонний подход: «Вместо того, чтобы просто представлять такие пространства как репозиторий отчуждения и одиночества, мы должны исследовать их возможности для создания современных форм отношений и, соответственно, идентичности и значения». Трибел называет не-места пробным камнем новых идентичностей и приходит к выводу о том, что не-место может иногда играть роль трансцендентного места 
(Triebel 2015: 100). Трибел также указывает на диахроническое изменение, упоминая, что в прошлом значимые антропологические места действительно могли доминировать над ничего не значащими не-местами, и не-местам всегда приходилось следовать правилам, заложенным антропологическими местами, но в современном глобализированном мире это может больше не происходить. Трибел заканчивает вопросом: «Разве в нашем транскультурном, всё более взаимосвязанном мире не-места не стали фрактически новыми центрами значения, где встречаются разные люди, услуги и идеи?» (Triebel 2015: 100). Тим Крессуэлл пишет о возможности получения осмысленного опыта и привязанности в современных не-местах, характеризуя их как «угнездившуюся мобильность» (Cresswell 2006: 257).

Было бы также необходимо уделить больше внимания аспектам субъективности, интерсубъективности и временности: восприятие некоторых пространств как не-мест может быть не постоянным и не одинаковым для разных людей и при разных обстоятельствах, а может зависеть от душевного состояния человека в данный момент. Я поддерживаю Дилана Тригга, который также упоминает о темпоральности в своих рассуждениях об отношениях и философии, связанной с не-местами: «Временами они [не-места] открывают в себе важное значение, а в другое время они становятся временными местами, нечёткими и взаимозаменяемыми» (Trigg 2017: 128). Соответственно, нужно учитывать, что наше отношение с действительностью включает большое число факторов, что формирует наше представление об окружающем нас мире (см. Trigg 2017: 134). Значение, приписываемое локации, зависит от соответствующего личного нарратива индивида, который может преобразовать эту локацию для себя в священный объект или в не-место. Похожую мысль высказывает Регина Бендикс в своих рассуждениях об аутентичности впечатлений: согласно Жану Бодрийяру, подлинное и ложное смешиваются, их идентичности разделяются только их нарративами (Bendix 1997: 4). Следовательно, нарративы, часто объединяемые с личными впечатлениями и чувствами, которые относятся к месту, играют решающую роль в том, связана ли (и если да, каким образом) идентичность человека с данным местом, и открывают в нём священное, историческое или другое личное измерение. 


\section{Священные места и не-места: формы симбиоза и гибридизации}

Есть много определений священных мест, сформулированных как исследователями, так и посетителями этих мест, чьи представления о том, что делает место священным, могут разниться. Базовое и довольно широкое определение, которое лучше всего вписывается в контекст этой статьи, звучит следующим образом: священное место - это место, которое воспринимается как сакральное, где проводится духовное поклонение и соответствующее ритуальное поведение вне зависимости от деноминации или веры пользователя этого места. Исторически, священными местами в Эстонии (как и во многих других культурах) были природные места (например, священные рощи), созданные человеком места (христианские церкви, часовни) и места, которые сочетали обе эти характеристики (например, естественные камни со сделанными человеком гравировками). Объединяет их то, что у них было фоксированное местонахождение и довольно фриксированная религиозная фрункция.

В современной западной культуре восприятие священного пространства подвержено динамическим изменениям. Традиционные фриксированные ритуальные формы используются реже и появляются новые формы: традиционные священные места меняют свою функцию, новые ритуальные места, в том числе и городские, становятся всё более популярными. С одной стороны, концепции священности стали более гибкими в индивидуализированном, пост-светском обществе; с другой стороны, паутину значений, которая опутывает опыт, связанный с сакральностью, легче перенести в нетрадиционные места, такие как городские не-места.

Далее я предлагаю четырёхстороннюю классификацию отношений между не-местами и священными местами. Это не исчерпывающий список всех возможных форм сочетания, но он продемонстрирует некоторые примеры смешивания или гибридизации двух типов пространств, которые кажутся довольно типичными для культурных тенденций современного западного общества. 


\section{Не-места, приближающиеся к священным местам}

В этой категории сравнение проводится главным образом между коммерческими объектами (например, торговыми центрами) как типичными не-местами и традиционными священными местами. Профрессор теологии и историк Джон Пал описывает в своей работе «Торговые центры и другие священные пространства» (2003) квази-религиозную природу торговых центров и коммерческих брендов (таких как Мир Уолта Диснея), приводя в пример коммерческих идолов американского общества и «храмы», где их почитают. В подобном ключе Ира Зепп, теолог и феноменолог религии, исследует разные способы пространственной организации торговых центров согласно космологическим принципам и их использование в качестве вместилища большого количества символов, объектов и действий, наполненных сакральным смыслом. По мнению Зепп, торговые центры можно рассматривать как заменители древних священных центров, вышедших из или основанных на мифологии axis mundi, оси мира. Лиза Шараун добавляет социальный аспект, указывая на то, что современные «храмы консьюмеризма» фрункционируют для некоторых демографических групп как основное место социального взаимодействия - так же, как храмы и церкви в прошлом (см. 2012: 1). Представляется, что торговые центры выполняют даже больше (квази)религиозных фрункций: они функционируют циклическим образом, что во многом соответствует обрядовому циклу христианства или сакральным периодам народного календаря (например, особые празднования Рождества и Пасхи; коммерческие ярмарки в честь Девы Марии или св. Мартина в некоторых городах Эстонии).

Майкл О’Реган и Джейон Чо (2014) провели наблюдение за не-местами с несколько другого ракурса, разглядывая традиционное религиозное поведение, которое перешло в определённые коммерческие контексты, в частности, в современные туристические казино в Макао. Авторы приводят примеры того, как посетители казино в Макао ведут себя как квази-пилигримы, демонстрируя ритуальное поведение, сходное с поведением традиционных пилигримов: приносят подношения, читают молитвы, носят талисманы, посещают традиционные храмы перед азартными играми, чтобы обеспечить себе удачу в игре. 
Тем не менее, торговые центры и другие коммерческие пространства не кажутся совместимыми со священными местами в каждом их аспекте: хотя многие коммерческие объекты и продукты предлагают вечную жизнь (например, благодаря омолаживающим товарам или процедурам), в них сложно увидеть экзистенциальное и трансцендентальное измерение, которое характерно для традиционных священных мест. Но тем не менее анализ показывает, что границы между не-местами и священными местами могут быть более размытыми, чем предположил бы Оже.

\section{Священные места внутри не-мест}

Согласно описанию Оже, не-места имеют достаточно статичный, неизменный характер. Однако если мы возьмём в качестве примера автомобильные трассы, даже части одной трассы могут иметь разные личные или коллективные значения и соответственно, обладать разными духовными и эмоциональными качествами. На трассах есть места, которые вызывают страх и ужас из-за определённых нарративных традиций, например, места, связанные с сюжетом об исчезающем автостопщике (см., например, Bennett 2011). Иногда такие истории связаны с определёнными местами, которые часто визуально отмечены на трассе, в частности, придорожными памятниками, которые, в свою очередь, несут в себе особое значение - скорбь и привязанность к родственникам жертвы дорожного происшествия, которая увековечена данным придорожным памятником (больше о придорожных памятниках см. Margry \& Sánchez-Carretero 2011; Yudkina \& Sokolova 2014). Нарративные традиции, связанные с такими участками трассы, могут вызывать определённые защитные реакции у людей, которые проезжают эти места (особенно если они едут в одиночку в тёмное время суток), например, люди крестятся или читают молитву, проезжая через это место. Так эти участки могут стать одновременно местами страха и местами преодоления страха путём религиозного поведения. Следовательно, эти точки на трассе могут найти себе место на личных ментальных картах ужаса или надежды и вписаться в контекст нарративных традиций и мысленных образов (более подробно о нарративных картах, связанных с опасностями, см. Hiiemäe 2016a). 
Привлекают также внимание определённые священные узлы на трассах - придорожные часовни в местах стоянок фур. Они встречаются главным образом в Северной Америке и их внешний облик разнится: они могут быть просто коробками без окон, выглядящими как очередной трейлер, но со знаком «Часовня», но в некоторых случаях интерьер трейлеров также напоминает традиционную сакральную архитектуру, например, в некоторых придорожных часовнях есть канделябры, ковры, деревянная панельная обшивка, и т.д., а также капелланы, с которыми можно поговорить двадцать четыре часа в сутки. С течением времени многие водители фрур, проезжая большие расстояния по одному и тому же маршруту, чувствуют себя «как дома» на некоторых стоянках или в часовнях. Такие локусы могут создавать ощущение знакомого места, принадлежности к нему и иногда духовного облегчения (более подробно о значении стоянок фур см. Kozak 2012: 294 ff). Молитвенные комнаты или часовни в аэропортах или больницах также служат местами для молитвы и/или общения со сверхъестественными силами и опять-таки, только от самого человека и его субъективного восприятия зависит, будут ли эти места иметь для него глубокую духовную значимость или это будет просто тихое место, чтобы укрыться от толпы.

Другим примером священных мест в не-местах являются церкви, расположенные в торговых центрах. Иногда церкви въезжают в вакантные точки в торговых центрах, представляя собой, таким образом, «смесь розничной торговли и религии» (Dietz 2010), но они также могут занять целые комплексы обанкротившихся торговых центров, например, в некоторых местах Канады и Северной Америки церкви заняли помещения известной коммерческой сети Wal-Mart и преобразовали их в культовые места (McFarland Taylor 2017: 247, 253; Dietz 2010). На полпути между не-местами и священными местами находятся магазины эзотерики, которые, с одной стороны, функционируют как коммерческие предприятия, а с другой стороны, организуют спиритические сеансы и ритуалы в тех же помещениях, временно преобразуясь для их участников в места духовных экспериментов и диалогов со сверхъестественным и привлекая людей со схожими интересами, из которых могут формироваться небольшие группы на основе постоянного участия в таких мероприятиях, которые могут также иногда проходить в других, более традиционных местах (например, посещения природных священных объектов). 


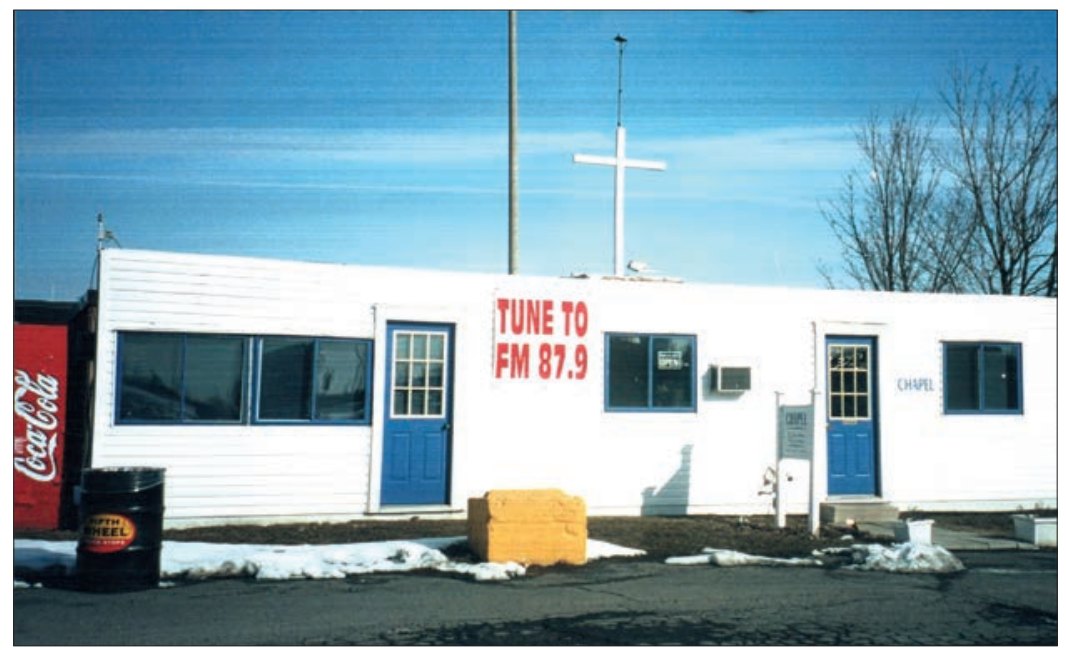

Фото 1. Передвижные капеллы и церкви в США и Канаде можно увидеть на многих стратегических стоянках для фур. Фото: https:// www.openroadchapels.ca/history/.

\section{Священные места, приближающиеся к не-местам}

Среди новых зданий церквей можно также заметить тенденции к использованию внешнего оформления, характерные для немест. Веками под влиянием тех или иных исторических эпох, событий и мировоззрений определённые символические элементы становились частью модели оформления церкви, оповещая о присутствии Бога посредством церковной архитектуры. В последние полвека, частично в результате изменений в литургии и архитектурных тенденциях, и частично по әкономическим причинам, большое количество современных церквей и других священных зданий строятся в функциональном, минималистичном, техноцентричном стиле, похожими на не-места, такие как торговые центры, офисные здания и приёмные докторов. Архитектор Эдуард Андерс Совик, один из пионеров (пост)модернистского минималистского церковного оформления, назвал такие функциональные церкви пространствами, которые часто 
предназначены не исключительно для священных ритуалов, но также могут быть приспособлены для других функций в качестве «не-церковных» зданий (Sövik 1973). Его современные идеи оформления церкви приветствовались многими, но среди посетителей церкви и архитекторов есть также и его противники, которые считают, что такие изменения традиции неподобающие, потому что эти фрункциональные не-церковные здания не создают ощущения Дома Божьего и, следовательно, осложняют контакт с Богом (см. Vosko 1997: 28; Vosko 2006). Например, Марк Торгерсон утверждает, что было бы ошибочным планировать внешнюю структуру, пропорции и украшения церкви в соответствии со стилем профанной архитектуры своего времени, чтобы привлекательность здания церкви не относилась только к этому миру (Torgerson 2007: 232). Однако он считает некоторые изменения в стиле неизбежными: «Здание церкви сегодня предназначено для людей нашего времени. Следовательно, оно должно быть смоделировано таким образом, чтобы люди нашего времени поняли и почувствовали, что оно адресовано им» (Torgerson 2007: 232). Соответственно, даже те, кто не поддерживает идею смешивания не-мест со священной архитектурой, могут посчитать эту тенденцию неизбежной в свете современных культурных изменений.

\section{Не-места, временно превращающиеся в священные места}

Можно найти всё больше случаев, когда не-места временно превращаются в культовые и ритуальные места. Эта черта может идти рука об руку с более или менее форсированными формами адаптации. Например, иммигранты и беженцы, находящиеся в лагерях беженцев, могут быть вынуждены строить временные молельные дома или церкви из ткани, картона или других подручных материалов для проведения своих литургий и других религиозных практик, чтобы удовлетворить свои духовные потребности; иммигрантам может понадобиться сменить свои традиционные святилища, которые они использовали для богослужений в родной стране, на здания, доступные в принимающей стране и таким образом развить новые религиозные запросы и формы (больше о фрормах религиозности в контексте миграции см., например, Horstmann \& Jung 2015; Frederiks \& Nagy 2016). 


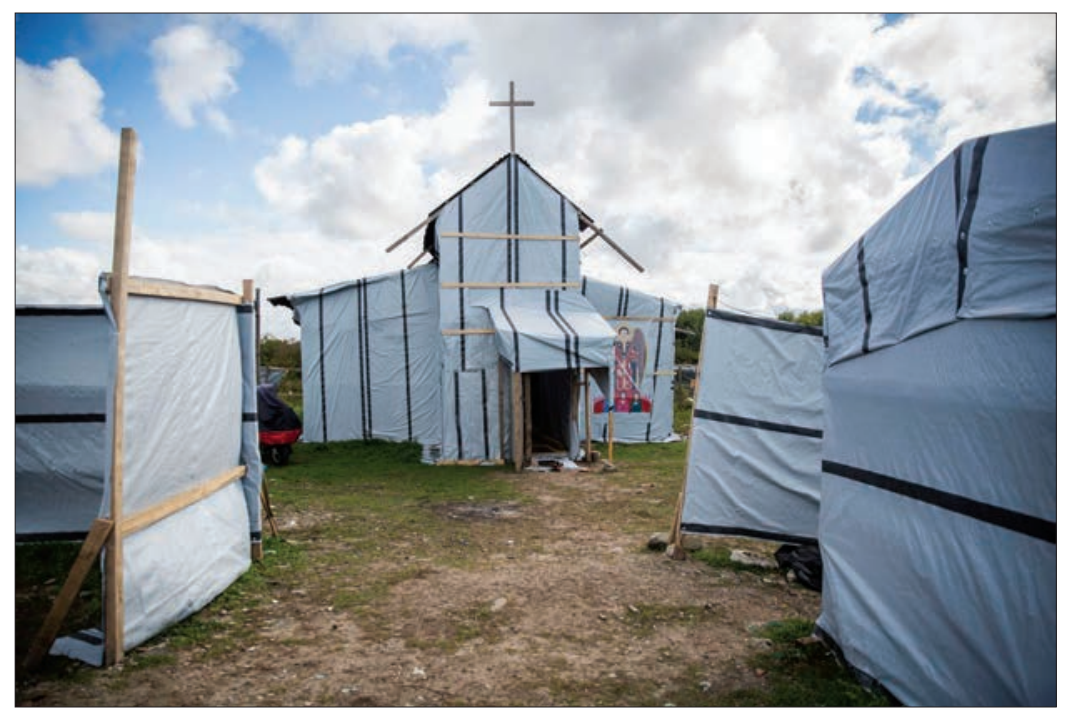

Фото 2. Временная церковь, построенная из подручных материалов, в г. Кале во Франции. Фото: http://mashable.com/2015/09/15/ calais-jungle-photos/\#Xbd2K0SUUgqk, 2015.

В других случаях не-места могут превращаться во временные священные места главным образом по соображениям удобства: ритуалы, которые раньше проводились в отдалённых природных священных местах, могут переноситься в городские офисные здания с целью обеспечения большей лёгкости доступа для городских искателей духовности. Таким образом, симптоматично, что когда оседлое население становится более мобильным и городским, их духовность тоже должна стать мобильной и духи должны следовать за своими почитателями в города или другие страны. Зигмунт Бауман (2000) использует термин "текучая современность» для описания таких процессов культурных изменений. Согласно Бауману, современное западное общество живёт ни в эпоху модерна, ни в эпоху постмодерна, а в текучем промежуточном состоянии, которое характеризуется двойственностью, размыванием и потерей категорий идентичности, которые раньше казались стабильными; это эра, когда социальные формы и институты меняются и могут находить новые текучие выходы: в нашем случае не-места, которые могут 
иногда брать на себя фрункции священных мест. Ниже - всего несколько примеров этого:

Анализ кейса 1: Интерактивный табачный ритуал в Тарту, проводимый шаманом из Эквадора

В марте 2014 г. в конференционном зале конференционного центра и ночного клуба в Тарту, Эстония, был проведён табачный ритуал с шаманом из Эквадора. Ритуал проводил молодой космополитичный шаман, который утверждал, что он получил свои знания из аутентичной шаманской традиции южноамериканских джунглей, которую он, однако, сочетает с китайской медициной и боевыми искусствами, которым он обучался в другим местах. Ритуальные действия (нюхание табачной смеси и наблюдение за своей реакцией и ощущениями) сопровождались экзотическими племенными нарративами, которые рассказывал шаман, но его внешний облик оставался современным: он был одет в джинсы и не считал традиционный костюм необходимым маркером своего статуса. Участников призывали использовать свою фантазию, войти в духовный контакт с табаком, природой, своим животным духом-покровителем и т.д. В конце была общая дискуссия, где каждый мог рассказать о своём опыте, и несколько участников сказали, что почувствовали присутствие шаманских духов. Пояснения давались на английском, и шаман утверждал, что его духи коренных индейских племён понимают английский и могут сопровождать его, куда бы он ни поехал. Ритуал соответствовал вкусам людей, которые пришли ради забавы и из любопытства, но также за серьёзным духовным ростом. Этот же шаман проводил подобный ритуал в Таллинне в городском заведении под название «Oasis», которое на своём сайте описывается как портал к природе в центре города. Так на уровне воображения опять создавалась связь с природой. Это событие рекламировалось как «Табачный ритуал в день Святого Валентина в полнолуние», тая в себе ещё больше символов и значений из разных времён и культур.

Анализ кейса 2: Ритуал прохождения через костёр в офисном здании в Тарту

Обычно такие ритуалы прохождения через костёр проходят в деревенском дворе несколько раз в году (особенно в связи с днями солнцестояния). Но в тот день в фреврале 2014 г., 


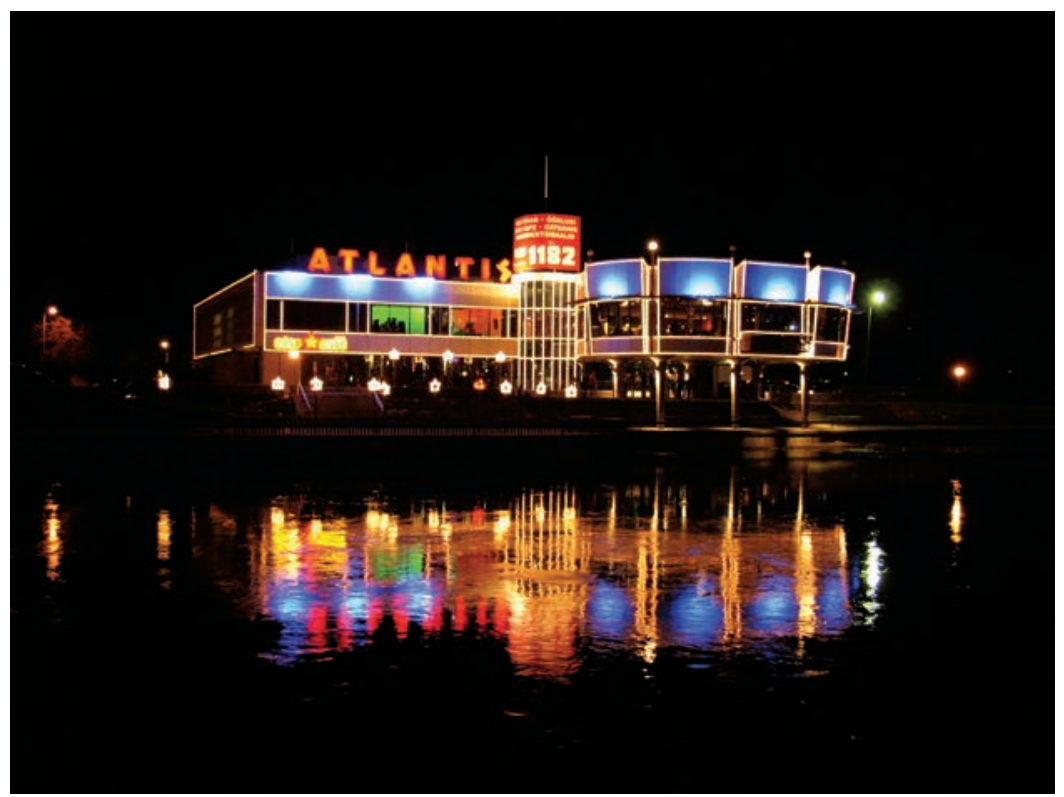

Фото 3. Ночной клуб и конференц-центр в г. Тарту, функционировавший также в качестве ритуального места. Фото: Андрес Пийр, http://www. panoramio.com/photo/3237530, 2007.

который был выбран для ритуала, погода была необычайно холодной, поэтому организаторы решили провести его в офисном здании в центре Тарту. В результате, ритуал прохождения через костёр проводился без костра. Отсутствие костра компенсировалось использованием свечей, работой фантазии и поведенческой имитацией. Участники должны были представить, что они сидят у большого костра и чувствуют его жар, потом их попросили представить, как они проходят через огонь. В случае временных городских священных мест часто ищется виртуальная или воображаемая связь с реальными священными местами на природе, чтобы подкрепить этот опыт. Природные священные места всё ещё являются важным элементом идентичности многих эстонцев, однако только $31 \%$ населения Эстонии посещает природные священные места не меньше раза в год (согласно опросу 2014 г.). 


\section{Заключение}

(Временное) перемещение священного пространства в города можно рассматривать как одну из черт той динамики, которая характерна для продолжающейся урбанизации и тенденций к мобильности в обществе, и изменений в духовности и восприятии пространства, связанных с ней. С одной стороны, духовные практики переносятся в городские не-места по причине удобства для потребителей, с другой стороны, эта тенденция восходит к необходимости «одомашнить» не-места и удовлетворить свои духовные потребности недалеко от дома или другого места пребывания (например, в лагерях беженцев, аэропортах, на новой родине). Во время этого процесса, часто с помощью мысленных образов, разные не-места могут стать местами значимости, духовных открытий и привязанности.

Следуя общей тенденции в современных обществах, коллективные и фиксированные религиозные идентичности теряют свою значимость, карающие боги монотеизма часто заменяются дружелюбными и более человечными духовными существами, такими как ангелы или духи умерших родственников. Гибкий выбор отдельного человека приобретает всё большую важность; в ряде случаев духовные практики сочетаются с элементами забавы. В более древней традиции, духи священных рощ или камней были связаны с определёнными географическими местами. Современные духи преодолевают границы городов, государств и языков, например, эквадорские шаманские духи могут быть вызваны везде, где проводится табачный ритуал; гаитянские иммигранты могут связаться с гаитянскими духами вуду также в подвалах Нью Йорка. Плюрализм, эклектизм и текучесть, характерные для современных верований и ритуального поведения, также проявляются в использовании места: монофункциональность заменяется полифункциональностью и культурной гибкостью. Таким образом, священные места всё чаще становятся портативными, так как подходящий «алтарь», «передвижной храм» или другая среда может быть организована в любом месте участниками, что делает живые духовные практики возможными также в не-местах. 


\section{Выражение благодарности}

Работа над статьёй осуществлена при поддержке Министерства образования и науки Эстонии (институциональный исследовательский грант IUT 22-5) и Фонда регионального развития EC (Центр компетенции по Эстонским исследованиям CEES TK 145).

\section{Литература}

Augé, Marc 2008. Non-places: An Introduction to Supermodernity. 2nd ed. London: Verso.

Bauman, Zygmunt 2000. Liquid modernity. Cambridge: Polity Press.

Bendix, Regina 1997. In Search for Authenticity. The Formation of Folklore Studies. Madison: The University of Wisconsin Press.

Bennett, Gillian 2011. Phantom Hitchhikers and Bad Deaths. Tradition Today 1 , cc. $3-18$.

Cresswell, Tim 2006. On the move: mobility in the modern western world. New York: Routledge Taylor \& Francis Group.

Dietz, Diane 2010. A mix of retail and religion: mall ministry. The RegisterGuard, D10.

Frederiks, Martha \& Nagy, Dorottya (ред.) 2016. Religion, Migration and Identity. Methodological and theological explorations. Leiden, Boston: Brill.

Hiiemäe, Reet 2016. Folkloor kui mentaalse enesekaitse vahend: usundilise pärimuse pragmaatikast. [Folklore as a means of mental self-defence: about the pragmatics of belief traditions.] Doctoral thesis. Tartu: University of Tartu Press.

Hiiemäe, Reet 2016a. Narrative Maps of Danger as a Means of Subjective Protection. Etnološka tribina 46 (39), cc. 176-186.

Horstmann, Alexander \& Jung, Jin-Heon (ред.) 2015. Building Noah's Ark for Migrants, Refugees, and Religious Communities. New York: Palgrave Macmillan. 
Kozak, Stephanie 2012. Home away from home: meanings of the American truck stop. Journal of Cultural Geography 29 (3), cc. 293-313.

Korstanje, Maximiliano E. \& Tzanelli, Rodanthi 2017. Passport, surveillance and reciprocity in travel: reconsidering hospitality through a criticism of marc augé's 'non-places'. Chapter 6. Joshua Morgan (ред.). Focus on Terrorism, Vol. 15. New York: Nova Science Publishers.

Lefebvre, Henri 2000. The Production of Space. Oxford, Malden: Blackwell (Пер. на рус.: Лефевр А. Производство пространства / Пер. с фр. И. Стаф. М.: Strelka Press, 2015).

Margry, Peter Jan \& Sánchez-Carretero, Cristina (ред.) 2011. Grassroots Memorials: The Politics of Memorializing Traumatic Death. New York: Berghahn.

McFarland Taylor, Sarah 2017. Shopping, Religion, and the Sacred Buyosphere. Bruce David Forbes \& Jeffrey H. Mahan (ред.). Religion and Popular Culture in America, Third Edition. Oakland: University of California Press, cc. 242-261.

O'Beirne, Emer 2006. Mapping the Non-Lieu in Marc Auge's Writings. Forum for Modern Language Studies 42 (1), cc. 38-50.

O'Regan, Michael \& Choe, Jaeyeon 2014. Pilgrims to Casinos in Macau. Vernacular Religion, Folk Belief, and Traditions of the Supernatural. Conference abstracts. Macau: Iceland Dynamics. http://www. islanddynamics.org/Supernatural\%20Conference $\% 202015 \% 20$ Programme.pdf.

Pahl, Jon 2003. Shopping Malls and Other Sacred Places. Putting Got in Place. Eugene: Wipf \& Stock

Scharoun, Lisa 2012. America at the Mall: The Cultural Role of a Retail Utopia. Jefferson: McFarland \& Company.

Sövik, Edward Anders 1973. Architecture for Worship. Minneapolis: Augsburg Publishing House.

Torgerson, Mark E. 2007. An Architecture of Immanence. Architecture for Worship and Ministry Today. Michigan, Cambridge: Wm. B. Eerdmans Publishing Co.

Triebel, Christian 2015. Non-Place Kids? Marc Auge's Non-Place and Third Culture Kids. Saija Benjamin \& Fred Dervin (ред.). Migration, Identity, and Education. Beyond Third Culture Kids. Helsinki: Palgrave, Macmillan, cc. 87-101. 


\section{Реэт Хийемяэ}

Trigg, Dylan 2017. Place and Non-place: A Phenomenological Perspective. В. В. Janz (ред.). Place, Space and Hermeneutics. (Contributions to Hermeneutics 5). Springer, cc. 127-139 (DOI: 10.1007/978-3-31952214-2_10).

Vosko, Richard S. 1997. Designing Future Worship Spaces: The Mystery of a Common Vision. Chicago: Liturgy Training Publications.

Vosko, Richard S. 2006. God's House is Our House. Re-imagining the environment for Worship. Collegeville: Liturgical Press.

Yudkina, Anna \& Sokolova, Anna 2014. Roadside Memorials in Contemporary Russia: Folk Origins and Global Trends. Religion and Society in Central and Eastern Europe 7 (1), cc. 35-51.

Zepp, Ira 1997. The New Religious Image of Urban America, Second Edition: The Shopping Mall as Ceremonial Center. Boulder, Logan: University Press of Colorado.

\section{Summary}

\section{Non-places as Sacred Places: Conflict, Contradiction, or Adaptation}

\section{Reet Hiiemäe}

Keywords: non-places, sacred places, dynamics of tradition, narratives, adaptation

French anthropologist Marc Augé invented the term non-places, which he defines as urban spaces of circulation, consumption, and communication that exist beyond historical, symbolic, and identityrelated ties. The focus of my paper is on the question, in which cases, and to what extent can such non-places temporarily become sacred places or spiritual spaces and therefore obtain spiritual, symbolic, and identity-related content. I try to find out how far is the (temporary) shifting of sacred space into cities a feature that is characteristic of the ongoing urbanisation and mobility trends, and changes in spirituality and perception of space connected with it. I argue that non-places are not necessarily indicators of alienation from spirituality, rootedness, and tradition (as several authors have claimed); quite the contrary, their temporary functioning as sacred places can be rather seen as a sign of adaptation and, in certain conditions (migration, refugee life), they can become the life buoys of the spiritual needs of groups and individuals. 


\section{МИССИЯ ВЫПОЛНИМА Перспективы изучения фольклора}

http://www.folklore.ee/rl/pubte/ee/sator/sator19/

ISSN 1736-0323

ISBN 978-9949-586-60-8

DOI: $10.7592 /$ Sator.2018.19

Тарту 2018

Редакторы-составители выпуска:

Маре Кыйва \& Татьяна Володина

Редактор серии: Маре Кыйва

Фото: Яак Кикас, 2018 «Осень в Тарту»

Оформление обложки: Лииса Весик

Верстка \& HTML: Диана Кахре

Печатное издание: МИССИЯ ВЫПОЛНИМА:

Перспективы изучения фольклора. SATOR 19. Тарту 2018

Публикация книги осуществлена совместно Эстонским литературным музеем и Центром исследований белорусской культуры, языка и лит ерат уры Националь ной акад емии наук Б еларус и, п ри поддержке Министерства образования и науки Эстонии (IUT 22-5), Фонда регионального развития ЕС (ТK 145, Центр компетенции по Эстонским исследованиям); при поддержке проекта, финансируемого Министерством иностранных дел Эстонии из бюджета по сотрудничеству и развитию, Эстонской Академией Наук и Национальной академии наук Беларуси.

Оформление электронного издания осуществлено при поддержке проекта ЕККМ14-344 “Расширение областей применения и представление эстонского языка, культуры и фольклора в электронных информационных средствах".

() Эстонский литературный музей

(c) Авторы

(с) Яак Кикас 